\title{
Fertilizing ability of spermatozoa from aged C57BL/6NNia mice
}

\author{
T. A. Parkening \\ Departments of Anatomy and Neurosciences, and Obstetrics and Gynecology, \\ University of Texas Medical Branch, Galveston, TX 77550, USA
}

\begin{abstract}
Summary. Spermatozoa from C57BL/6NNia mice (7- and 25-month-old males that produced offspring and 25-month-old males incapable of producing offspring which either mated or did not mate after being paired for 1 month with proven-fertile females) were tested in in-vitro fertilization studies. The 7-month-old males fertilized the largest number of oocytes $(80-86 \%)$ in vitro and $79 \%$ of them subsequently developed into blastocysts in culture. Aged males which failed to mate fertilized the lowest number of oocytes (11-19\%) with $48 \%$ developing to blastocysts. This group of mice had the lowest number of spermatozoa in the cauda epididymidis $\left(3 \cdot 2 \pm 0.4 \times 10^{5} / \mathrm{mg}\right.$ tissue) with fewer motile spermatozoa $(22 \cdot 3 \pm 5 \cdot 1 \%)$ than younger males. The percentage of spermatozoa retaining their acrosome after $3 \mathrm{~h}$ in culture was higher in aged males which had not mated when compared to younger males that had mated. After $4 \mathrm{~h}$ in culture, however, the number of spermatozoa that had lost their acrosome was almost identical in the two groups. Superovulated mice which were artificially inseminated with spermatozoa from 25 -month-old mice that had not mated did not become pregnant. Testosterone concentrations were lowest in aged mice not mating. These concentrations may explain the poor behavioural response of these males, but whether they account for the inability of spermatozoa to fertilize ova in vitro or in vivo after artificial insemination is not known.
\end{abstract}

Keywords: spermatozoa; in-vitro fertilization; aged mice; testosterone

\section{Introduction}

A previous study (Parkening et al., 1988) examined several biological parameters in ageing male C57BL/6NNia mice. A significant finding from that study was that less than half of the mice, 24 months of age, would mate with a young proven-fertile female mouse when housed together for 1 month. However, aged mice which did mate $(42 \%)$ and were capable of impregnating $(65 \%)$ a female produced a litter size similar to those produced by 6 -month-old mice. The majority of the aged mice which failed to mate still had adequate, although lower, numbers of motile spermatozoa present in their cauda epididymidis. Since it was not known whether the failure of these seemingly healthy mice to mate resulted from age-related changes in their behaviour or from unrecognized physiological changes, it was decided to examine their spermatozoa in vitro.

\section{Materials and Methods}

Animals. Virgin male C57BL/6NNia mice (6 and 24 months of age) were purchased from the National Institute of Aging colony maintained by Charles River Laboratories (Wilmington, MA, USA). They were housed under $14 \mathrm{~h}$ of artificial light $(06: 00$ to $20: 00 \mathrm{~h})$ in a temperature-controlled room $\left(21-23^{\circ} \mathrm{C}\right)$ and provided with mouse chow and water ad libitum. The mice were allowed to adjust to their new surroundings and 10 days later they were individually 
housed for 1 month with a proven fertile 4-month-old C57BL/6NNia female. Female mice were checked each morning for the presence of spermatozoa in the vaginal smear. At the end of the 1-month mating period males were classified as fertile breeders, non-fertile breeders or nonbreeders. The mice were then killed within 2 weeks and their spermatozoa were used for in-vitro fertilization or artificial insemination experiments.

Recovery and preparation of spermatozoa. A cauda epididymidis was removed from either a 7- or 25-month-old male, weighed and placed in a culture dish $(35 \times 10 \mathrm{~mm}$, Falcon 3005$)$ containing $0.5 \mathrm{ml}$ of previously incubated BWW medium (Biggers et al., 1971) containing $4 \mathrm{mg} \mathrm{BSA} / \mathrm{ml}$. The epididymis was cut several times with dissecting scissors and placed in the incubator $\left(37^{\circ} \mathrm{C}\right)$ in $5 \% \mathrm{CO}_{2}$ in air for $15 \mathrm{~min}$. The number of spermatozoa which had dispersed into the medium was determined using a haemocytometer and the number $/ \mathrm{mg}$ tissue recorded. The number of motile spermatozoa was also counted within the field of the haemocytometer.

For each male approximately $5 \times 10^{5}$ motile spermatozoa $/ \mathrm{ml}$ were suspended in a $200 \mu \mathrm{l}$ bubble of Medium BWW under paraffin oil in a Falcon plastic dish $(35 \times 10 \mathrm{~mm})$. Mice had to have some motile spermatozoa to be included in the study. Spermatozoa were allowed to capacitate for $2 \mathrm{~h}$ before adding ova to them. Spermatozoa were morphologically evaluated by mincing the contralateral epididymis in $1 \mathrm{ml}$ Hank's medium and allowing the spermatozoa to disperse as above. The sperm suspensions were then dried on microscope slides and silver stained according to Elder \& Hsu (1981) to assess their morphology. Spermatozoa were considered abnormal if they contained head malformations corresponding to classification 3-5 as devised by Krzanowska (1981) or if they contained more than one flagellum or an unusually shaped flagellum.

Superovulation, in-vitro fertilization and early embryo culture. Female C57BL/6NNia mice (2-4-months-old) were induced to superovulate by an intraperitoneal injection of 5 i.u. PMSG followed by 5 i.u. hCG $48 \mathrm{~h}$ later. Oviducts from the mice were excised 15-16 h after the injection of hCG and placed in paraffin oil in the culture dish. Under a dissection microscope the ampulla of each oviduct was torn open with a sterile dissecting needle and the ova within the cumulus mass which exuded into the oil were pushed into the droplet of Medium BWW containing spermatozoa. Ova were left with the spermatozoa for $8-9 \mathrm{~h}$ in a $37^{\circ} \mathrm{C}$ incubator in $5 \% \mathrm{CO}_{2}$ in air. They were then removed and either fixed ( $1 \%$ glutaraldehyde), mounted and stained (Parkening \& Chang, 1976) or washed twice in Medium BWW and placed in a new $200 \mu 1$ droplet of Medium BWW for subsequent development. Half of the ova were fixed and the other half cultured during each experiment. Cleavage was monitored at 08:00 and 16:00 h for the next 5 days and the eggs which did not appear fertilized or had fragmented were removed, fixed, stained and examined for the presence of spermatozoa.

Artificial insemination. A cauda epididymidis from each mouse was minced with microscissors in $1 \mathrm{ml}$ Medium BWW and placed in an incubator $\left(37^{\circ} \mathrm{C}\right)$ gassed with $5 \% \mathrm{CO}_{2}$ in air for $15 \mathrm{~min}$. Small pieces of tissue were removed with forceps and the sperm suspension collected with a blunted 21 -gauge needle $(2 \cdot 2 \mathrm{~cm})$ attached to 1 -ml syringe. Mice (4-5-months-old) which had previously produced at least 1 litter were induced to ovulate by an intraperitoneal injection of 5 i.u. PMSG followed $48 \mathrm{~h}$ later with 5 i.u. hCG. At $16 \mathrm{~h}$ after receiving hCG they were anaesthetized lightly with ether and inseminated with $50 \mu \mathrm{l}$ sperm suspension using a slight modification of the technique of Dziuk \& Runner (1960): a $1-\mathrm{cm}$ piece of Tygon tubing (i.d. $2 \mathrm{~mm}$, o.d. $5 \mathrm{~mm}$ ) was inserted into the vagina to the cervix before inserting the needle (bend half-way at $15^{\circ}$ angle) through the cervix into one uterine horn. The tubing acted as an artificial penis and provided an easier access to the uterus with less chance of perforating it. Only one uterine horn was injected since this quantity of fluid has been shown to overflow into the adjacent horn (Leckie et al., 1973). After insemination a vaginal tampon was inserted into the vagina as described by Leckie et al. (1973). The mice were killed on Day 10 or Day 18 after insemination to examine the uterus for fetuses.

Acrosome reaction. To detect any differences in the loss of the acrosome, spermatozoa were removed from culture dishes hourly, after incubation for I to $4 \mathrm{~h}$, and applied to a column bed $(2 \mathrm{~cm})$ of Sephadex G-25 prepared in Pasteur pipettes (Fraser \& Quinn, 1981). The motile spermatozoa leaving these columns were then stained by the procedure of Wells \& Awa (1970). The stain was prepared by combining $5 \mathrm{ml}$ of a $1.0 \%$ solution of eosin B (dissolved in distilled water), $10 \mathrm{ml}$ of a $1.0 \%$ solution of fast green FCF (dissolved in distilled water) and $8.5 \mathrm{ml}$ ethyl alcohol. A droplet of sperm suspension and the staining solution were mixed together for $\mathrm{I}$ min on a clean microscope slide and then smeared with a second slide and air dried at $37^{\circ} \mathrm{C}$ on a slide warming tray. Permanent slides were made using Permount under coverslips. At least 2 slides were prepared from five 7 -month-old and five 25 -month-old (non-mating) mice at each of the four time intervals, and 100 spermatozoa were examined from each slide for loss of the acrosome.

In two experiments spermatozoa from 7-month-old and 25 -month-old non-mating mice were allowed to capacitate for $1,2,3$ and $4 \mathrm{~h}$ before adding ova to determine whether increasing the time for capacitation improved the rates of fertilization.

Testosterone radioimmunoassay. Plasma testosterone concentration was determined for each mouse providing spermatozoa in this study (Table 1). A direct-testosterone RIA kit (Immuno Corporation, Carson, CA, USA) was used. A $25 \mu \mathrm{l}$ sample of unextracted plasma or $25 \mu \mathrm{l}$ standard material was incubated with ${ }^{125}$ I-labelled testosterone (40000 c.p.m. $/ \mathrm{ml}$ ) in antitestosterone-coated test tubes at $37^{\circ} \mathrm{C}$ for $120 \mathrm{~min}$. The contents of the tubes were then aspirated and the radioactivity of the bound hormone was counted and extrapolated from the standard curve. Sensitivity of the assay was $1.7 \mathrm{pg} /$ tube and the within assay variation was $8.3 \%$. 


\section{Results}

The greatest concentration of spermatozoa/mg wet weight of epididymis and the highest percentage of those spermatozoa exhibiting motility were found in 7-month-old C57BL/6NNia males (Table 1). The lowest number of spermatozoa was found in 25-month-old mice which did not mate. Sperm motility was reduced in this group when compared with younger mice. Three of the nonmating males contained no motile spermatozoa and were excluded from the study. The number of morphologically abnormal spermatozoa was higher in 25 -month-old males that mated and did not produce young when compared with young and aged mice producing offspring (Table 1).

Plasma testosterone concentrations in 7-month-old males, 25-month-old males that produced young, 25-month-old males that mated without producing young and 25-month-old males that did not mate were $5.2 \pm 1.6,4.2 \pm 2.0,1.6 \pm 0.2$ and $0.7 \pm 0.1 \mathrm{ng} / \mathrm{ml}$, respectively $(P<0.05$, ANOVA). Testosterone concentrations in 25 -month-old mice that did not mate were lower ( $P<0.05$ to $P<0.005$; Student's $t$ test) than those of mice in the other three groups.

Table 1. Values for spermatozoa from 7- and 25-month-old C57BL/6NNia mice

\begin{tabular}{cccccc}
\hline $\begin{array}{c}\text { Age } \\
\text { (months) }\end{array}$ & $\begin{array}{c}\text { No. of } \\
\text { mice }\end{array}$ & \multicolumn{1}{c}{ Category } & $\begin{array}{c}\text { No. of } \\
\text { spermatozoa/mg } \\
\text { epididymis }\end{array}$ & & \multicolumn{2}{c}{ Motile } & Abnormal \\
\hline 7 & 6 & Produced offspring & $10 \cdot 7 \times 10^{5} \pm 0 \cdot 4^{\mathrm{a} * *}$ & $50 \cdot 2 \pm 3 \cdot 8^{\mathrm{a} * *}$ & $7 \cdot 0 \pm 0 \cdot 6^{\mathrm{a} *}$ \\
25 & 4 & Produced offspring & $6 \cdot 5 \times 10^{5} \pm 0 \cdot 3^{\mathrm{b}}$ & $39 \cdot 0 \pm 3 \cdot 3^{\mathrm{ab}}$ & $6 \cdot 9 \pm 0 \cdot 5^{\mathrm{a}}$ \\
25 & 4 & Mated (no offspring) & $5 \cdot 8 \times 10^{5} \pm 0 \cdot 2^{\mathrm{b}}$ & $35 \cdot 0 \pm 7 \cdot 0^{\mathrm{ab}}$ & $9 \cdot 0 \pm 0 \cdot 7^{\mathrm{b}}$ \\
25 & 8 & Did not mate & $3 \cdot 2 \times 10^{5} \pm 0 \cdot 4^{\mathrm{c}}$ & $22 \cdot 3 \pm 5 \cdot 1^{\mathrm{b}}$ & $8 \cdot 4 \pm 0 \cdot 7^{\mathrm{ab}}$ \\
\hline
\end{tabular}

Values (mean \pm s.e.m.) with different superscripts are significantly different.

${ }^{*} P<0.05 ;{ }^{* *} P<0.005$, Student's $t$ test.

\section{In-vitro fertilization}

Spermatozoa from the 7-month-old male mice fertilized the highest percentage of oocytes in vitro (Table 2). Of the three categories of 25 -month-old mice, those that had sired a litter fertilized the greatest number of oocytes, whereas those that had failed to mate fertilized the least number of oocytes in vitro. Motile spermatozoa from aged mice not mating sustained their motility as long as did other spermatozoa. These same spermatozoa also released sufficient quantities of hyaluronidase in culture to clear the cumulus cells from the ova as rapidly as did spermatozoa from the other three groups of mice. These spermatozoa also appeared to make contact with the zona pellucida of the egg but did not fertilize it.

All of the ova listed in Table 2 were mounted, fixed and stained. Fertilized ova were monospermic except for one dispermic egg fertilized by a 7-month-old male. There was nothing unusual noted in the early fertilization (e.g. sperm penetration, formation of pronuclei) by spermatozoa from any of the groups.

\section{Embryo culture}

The number of eggs cultured that divided to the 2-cell stage (Table 3) was greatest if they had been fertilized in vitro with spermatozoa taken from mice that had produced offspring, regardless of the animal's age. Aged males mating without offspring and those that did not mate had considerably fewer eggs cleave to the 2-cell. It was apparent by the late 2-cell and early 4-cell stages which ova had not been fertilized (Fig. 1). Those that did not cleave or became fragmented were 
Table 2. In-vitro fertilization of C57BL/6NNia mouse ova by spermatozoa from 7- and 25-month-old males

\begin{tabular}{ccll}
\hline $\begin{array}{c}\text { Age } \\
\text { (months) }\end{array}$ & $\begin{array}{c}\text { No. of } \\
\text { mice }\end{array}$ & \multicolumn{1}{c}{ Category } & \multicolumn{1}{c}{ Fertilized (\%) } \\
\hline 7 & 6 & Produced offspring & $68 / 80(86 \pm 6 \cdot 9)^{*}$ \\
25 & 4 & Produced offspring & $45 / 84(56 \pm 6 \cdot 4)$ \\
25 & 4 & Mated (no offspring) & $24 / 82(29 \pm 3 \cdot 4)$ \\
25 & 8 & Did not mate & $19 / 182(11 \pm 2 \cdot 9)$ \\
\hline
\end{tabular}

Results are from 4 separate experiments.

*Each percentage (mean \pm s.e.m.) differs from the preceding percentage $(P<0.05$, Student's $t$ test $)$.

unfertilized. Fertilized eggs cleaved normally to the 2-cell stage and generally the 4-cell stage before halting their development. The number of fertilized eggs capable of developing into blastocysts from the four groups (Table 3 ) was not statistically different, although the variability within and between experiments (range $0-76 \%$ ) for 25-month-old mice mating without producing young and 25-month-old non-mating mice was extensive.

Table 3. Fertilization and subsequent development of C57BL/6NNia mouse ova in vitro

\begin{tabular}{clccccc}
\hline $\begin{array}{c}\text { Age } \\
\text { (months) }\end{array}$ & \multicolumn{1}{c}{ Category } & $\begin{array}{c}\text { No. of } \\
\text { ova }\end{array}$ & $\begin{array}{c}\text { 2-cell } \\
(\%)\end{array}$ & 4-cell & $\begin{array}{c}\text { Early } \\
\text { morulae }\end{array}$ & $\begin{array}{c}\text { Blastocysts } \\
(\%)\end{array}$ \\
\hline $7(6)^{*}$ & Produced offspring & 92 & $74(80 \pm 6 \cdot 9)^{\mathrm{a}}$ & 69 & 60 & $60(79 \pm 6 \cdot 1)$ \\
$25(4)$ & Produced offspring & 90 & $60(68 \pm 6 \cdot 9)^{\mathrm{a}}$ & 54 & 50 & $45(73 \pm 5 \cdot 1)$ \\
$25(4)$ & Mated (no offspring) & 67 & $25(36 \pm 7 \cdot 6)^{\mathrm{b}}$ & 20 & 15 & $15(49 \pm 16 \cdot 4)$ \\
$25(8)$ & Did not mate & 269 & $50(19 \pm 2 \cdot 6)^{\mathrm{b}}$ & 42 & 26 & $24(48 \pm 16 \cdot 1)$ \\
\hline
\end{tabular}

*No. of mice indicated in parentheses.

Results are from 4 separate experiments.

Percentages (mean \pm s.e.m.) with different superscripts differ $(P<0.05$, Student's $t$ test $)$.

\section{Artificial insemination}

It was apparent that spermatozoa from aged males which had not mated were fertilizing the fewest eggs in vitro. To determine whether a similar loss might occur in vivo, artificial insemination was attempted.

Of 6 mice inseminated with spermatozoa from 7 -month-old mice, 3 were pregnant when killed at 18 days after insemination. They contained a total of $12(6,5,1)$ normal fetuses. None of 8 mice inseminated with spermatozoa from 25-month-old males that had not mated became pregnant: 4 were killed 18 days after insemination and 4 after 10 days to determine whether early embryos had died shortly after implantation and were being resorbed.

\section{Acrosome loss}

It was possible that the spermatozoa from non-mating males were not capacitating properly in vitro. To investigate one aspect of this process, spermatozoa were removed each hour during the 4-h incubation and examined for the retention or loss of the acrosome. At 1 and $2 \mathrm{~h}$ there were no differences between the two age groups in the loss of the acrosome (Fig. 2). After $3 \mathrm{~h}$ there was a significant difference $(P<0.05$, Student's $t$ test) because spermatozoa from 25 -month-old mice did not continue to exhibit a linear progression in the loss of the acrosome (Fig. 2). There were slightly fewer spermatozoa at this interval than at $2 \mathrm{~h}$ that had lost their acrosome. Many spermatozoa 



Fig. 1. Two- and 4-cell embryos derived from ova fertilized in vitro by spermatozoa from (a) a 7 -month-old mouse and (b) a 25 -month-old mouse that had failed to mate. The ova were inseminated $8-9 \mathrm{~h}$ in culture, washed and placed in fresh Medium BWW to observe their development. The photographs were taken after culture for $48 \mathrm{~h}$. In (b) only one 4-cell embryo (arrow) appeared normal. $\times 120$.

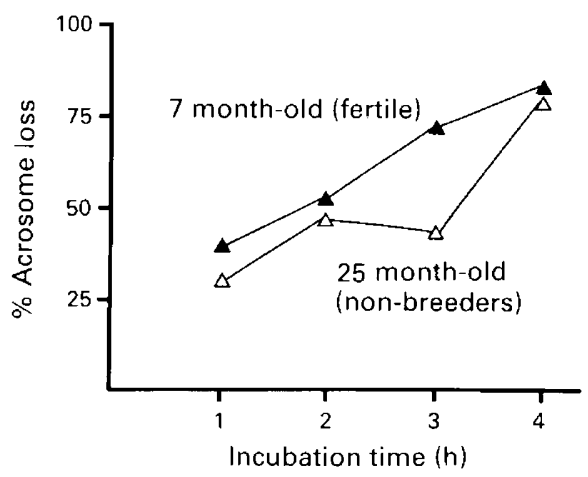

Fig. 2. The percentages of spermatozoa from 7-month-old and 25-month-old non-mating mice that lost their acrosome during an incubation of $1-4 \mathrm{~h}$ in Medium BWW.

from the older mice, however, did lose their acrosome between 3 and $4 \mathrm{~h}$, because the number of spermatozoa without an acrosome $(79 \%)$ was similar to those $(82 \%)$ from 7 -month-old mice. Spermatozoa from the non-mating aged males may still have not completely capacitated because preincubating the spermatozoa for as long as $4 \mathrm{~h}$ before the addition of eggs did not increase the percentage of eggs fertilized.

\section{Discussion}

Spermatozoa were still being produced in the testes of all male mice in this study. In non-mating mice spermatozoa accumulate and age in the male tract, and so it is highly probable some are 
inherently inferior. Spermatozoa artificially aged by ligation of the cauda epididymidis of the mouse for 6-20 days led to a significant increase in chromosomal anomalies of paternal origin at first-cleavage metaphase (Martin-DeLeon \& Boice, 1982). This was also true when first-cleavage zygotes were examined from mice mated to males sexually rested for 14 or more days compared to 3-day rested mice (Martin-DeLeon \& Boice, 1985). On the basis of the latter study it might be expected that there would be a paternal-age effect in the mouse, since older mice may copulate less frequently.

A paternal-age effect was not detected in a recent study when comparing litter sizes or congenital defects in young sired by 6- and 24-month-old mice (Parkening et al., 1988). However, only $42 \%$ of the aged mice mated. All of the mice in that study and in our present study were virgin when received at 5 and 23 months of age. They were housed individually for 1 month before the introduction of a single female. As a group the older mice which produced copulatory plugs took longer to mate than did the younger mice. This behaviour may have resulted from their prolonged period of social isolation (Huber \& Bronson, 1980). Huber \& Bronson (1980) were able to stimulate some aged $\mathrm{CBF}_{1}$ virgin males to mate after repeated exposures (5-day periods) to receptive females. In our studies males were housed with the same female for 1 month. Some of the aged males not mating were then tested after that month by adding a new female or a group of 3 females. This did not provide any additional incentive for these mice to mate.

From the present study it appears that some of the spermatozoa from aged males are inferior. Aged males which mated and produced offspring fertilized $12-30 \%$ fewer eggs in vitro than did those from younger males, although the percentage of zygotes capable of developing into blastocysts appeared comparable to those fertilized by younger males. This agrees with our previous study (Parkening et al., 1988) in which we found no decline in litter size between the two age groups. Aged males which mated and did not produce young and those not mating fertilized only $29-36 \%$ and $11-19 \%$ of eggs respectively, in vitro. Both of these groups also showed a greater variability in the number of eggs fertilized in vitro which were capable of developing into blastocysts. Non-mating mice were also incapable of fertilizing ova when their spermatozoa were artificially inseminated.

Aged male mice that produced offspring do not appear to be contributing to embryo loss, based on the litter size they produced and a preliminary chromosomal study of implanted embryos (Parkening et al., 1988). More extensive chromosomal studies are necessary, however, to verify these findings. Mice which did not mate would have to be eliminated from the evaluation of a paternal-age effect. This leaves aged males that mated and did not produce offspring as the group most likely to be representative of a paternal ageing factor. The group represented $35 \%$ of those mating in the previous study (Parkening et al., 1988) and $26 \%$ in the present study. It is not known whether the spermatozoa from these mice are capable of fertilizing ova in vivo and the embryos are lost early in development. In vitro their spermatozoa fertilized very few ova, although statistically there were no differences in the number fertilized that were capable of developing into blastocysts. Studies need to be conducted in which these blastocysts are transferred to surrogate mothers to determine their developmental potential.

Very few studies have been undertaken to examine what role ageing may have on sperm morphology. Krzanowska (1981) in a study of ageing male KE (7-15-month-old) and CBA (10month-old) mice found little correlation between misshapen spermatozoa and advancing age, although the number of mice examined was rather small. The incidence of morphologically abnormal spermatozoa does not appear to increase dramatically with advancing age in the C57BL/6NNia mouse. Spermatozoa considered misshapen, however, were those with rather obvious malformations. Certainly more subtle changes in the sperm head may be occurring and a closer examination of head dimensions may reveal greater differences. In vitro, spermatozoa having minor changes in the head are more likely to penetrate the zona pellucida and fertilize ova than those with gross malformations (Krzanowska \& Lorenc, 1983). The fact that spermatozoa from aged non-mating males were capable of fertilizing $<20 \%$ of ova in vitro suggests that biochemical changes rather 
than morphological changes, are probably responsible for the low rate of fertilization. The number of dead or non-motile spermatozoa was highest in this group of mice. Toxic products from dead cells could have had an adverse effect upon living spermatozoa both in vivo and in vitro. It did appear, however, as if spermatozoa from aged mice not mating were capable of undergoing an acrosome reaction, although other steps necessary in the process of capacitation may be impaired. Many factors could be contributing to changes in the spermatozoa themselves (e.g. membrane permeability, enzyme alterations, lipid redistribution, nuclear stability) or in their milieu (e.g. testosterone concentrations, epididymal secretions, secondary sex secretions).

In addition to the quality, the quantity of spermatozoa produced by aged male mice may be a factor in fertilization. The epididymal sperm concentration in aged mice which produced young was approximately twice that of aged mice failing to mate. There was not a marked difference, however, when comparing the number of spermatozoa from aged males which mated and did or did not produce young in this study or in our previous study (Parkening et al., 1988).

The low concentrations of circulating testosterone present in aged male mice failing to mate may be responsible for changes in sexual motivation. It may also have an adverse effect on the maturation of spermatozoa or sperm metabolism, thus impairing their ability to fertilize ova in vitro. Whatever the cause, it is apparent that seemingly healthy aged male mice have a variable ability to mate and fertilize ova. Whether this condition represents age-related changes in the testes or central nervous system awaits further investigation.

I thank Dr S. Abeyawardene for assistance in conducting experiments on evaluating spermatozoa for loss of the acrosome. This study was supported in part by NIA grant AG-04753.

\section{References}

Biggers, J.D., Whitten, W.K. \& Whittingham, D.G. (1971) The culture of mouse embryos in vitro. In Methods in Mammalian Embryology, pp. 86-116. Ed. J. C. Daniel, Jr. W.H. Freeman and Company, San Francisco.

Dziuk, P.J. \& Runner, M.N. (1960) Recovery of blastocysts and induction of implantation following artificial insemination of immature mice. J. Reprod. Fert. 1, 321-33l.

Elder, F.F.B. \& Hsu, T.C. (1981) Silver-staining patterns of mammalian epididymal spermatozoa. Cytogenet. Cell Genet. 27, 31-38.

Fraser, L.R. \& Quinn, P.J. (1981) A glycolytic product is obligatory for initiation of the sperm acrosome reaction and whiplash motility required for fertilization in the mouse. J. Reprod. Fert. 61, 25-35.

Huber, M.H.R. \& Bronson, F.H. (1980) Recovery of sexual activity with experience in aged male mice. Exp. Aging 6, 385-391.

Krzanowska, H. (1981) Sperm head abnormalities in relation to the age and strain of mice. J. Reprod. Fert. 62, 385-392.
Krzanowska, H. \& Lorenc, E. (1983) Influence of egg investments on in-vitro penetration of mouse eggs by misshapen spermatozoa. J. Reprod. Fert. 68, 57-62.

Leckie, P.A., Watson, J.G. \& Chaykin, S. (1973) An improved method for the artificial insemination of the mouse (Mus musculus). Biol. Reprod. 9, 420-425.

Martin-DeLeon, P.A. \& Boice, M.L. (1982) Sperm aging in the male and cytogenetic anomalies. An animal model. Hum. Genet. 62, 70-77.

Martin-DeLeon, P.A. \& Boice, M.L. (1985) Sperm aging in the male after sexual rest: contribution to chromosome anomalies. Gamete Res. 12, 151-163.

Parkening, T.A. \& Chang, M.C. (1976) In-vitro fertilization of ova from senescent mice and hamsters. $J$. Reprod. Fert. 48, 381-383.

Parkening, T.A., Collins, T.J. \& Au, W.W. (1988) Paternal age and its effects on reproduction in C57BL/6NNia mice. J. Gerontol. 43, B79-84.

Wells, M.E. \& Awa, O.A. (1970) New technique for assessing acrosomal characteristics of spermatozoa. J. Dairy Sci. 53, 227-232.

Received 15 March 1989 